\title{
Analisis Pengaruh Program CSR PT. Indonesia Asahan Aluminium (PERSERO) dalam Meningkatkan Kesejahteraan Masyarakat Kabupaten Batu Bara, Sumatera Utara
}

\author{
Suci Etri Jayanti S*, Rusmewahni \\ STIE Bina Karya Tebing Tinggi \\ *Correspondence email: rusmewahni48@yahoo.co.id
}

\begin{abstract}
Abstrak. Tujuan Dari Penelitian ini adalah untuk mengetahui dampak Program Corporate Social Responsibility PT. Indonesia Asahan Aluminium terhadap kesejahteraan masyarakat Kabupaten Batu Bara. Variabel dalam penellitian ini terdiri dari Corporate Social Responsibility dan Kesejahteraan Masyarakat. Penelitian ini dilakukan pada masyarakat Kecamatan Sei Suka, Kabupaten Batu Bara sebanyak 56.078 jiwa, berdasarkan rumus slovin maka diperoleh sebanyak 100 responden untuk dijadikan sampel. Metode dalam penelitian ini adalah Deskriptif Kuantitatif dengan menggunakan instrumen berupa angket / kuesioner, observasi dan wawancara dengan pengukuran skala likert. Dari hasil Analisis Regresi Linier Sederhana menunjukkan bahwa Corporate Social Responsibility (CSR) berpengaruh positif terhadap Kesejahteraan Masyarakat. Berdasarkan Uji Koefisien Determinasi, nilai $\mathrm{R}$ menyatakan bahwa nilai adjusted $\mathrm{R}$ sebesar $35.9 \%$ yang artinya bahwa kesejahteraan Masyarakat dipengharui oleh Corporate Social Responsibility (CSR), sedangkan sisanya 63.1\% dipengaruhi oleh variabel lain yang tidak diteliti dalam penelitian ini. Dari hasil analisa secara parsial (Uji t), variabel independen Corporate Social Responsibility (CSR) berpengaruh secara signifikan terhadap variabel dependen yaitu Kesejahteraan Masyarakat. Hal ini dapat dilihat pada tabel Coefficient melalui pengujian hipotesis dapat diketahui hasil perhitungan secara parsial memiliki pengaruh dan nyata (signifikan) terhadap variabel Kesejahteraan Masyarakat.
\end{abstract}

Kata kunci: Corporate Social Responsibility; Kesejahteraan Sosial

Abstract. The purpose of this study was to determine the impact of the Corporate Social Responsibility Program of PT. Indonesia Asahan Aluminum towards the welfare of the people of Batu Bara Regency. The variables in this research consist of Corporate Social Responsibility and Community Welfare. This research was conducted on the people of Sei Suka Subdistrict, Batu Bara Regency as many as 56,078 people, based on the slovin formula, 100 respondents were obtained as samples. The method in this research is descriptive quantitative using instruments in the form of a questionnaire / questionnaire, observation and interviews with Likert scale measurements. From the results of Simple Linear Regression Analysis, it shows that Corporate Social Responsibility (CSR) has a positive effect on Community Welfare. Based on the Coefficient of Determination Test, the R value states that the adjusted $R$ value is $35.9 \%$, which means that the welfare of the community is influenced by Corporate Social Responsibility (CSR), while the remaining $63.1 \%$ is influenced by other variables not examined in this study. From the results of the partial analysis ( $t$ test), the independent variable Corporate Social Responsibility (CSR) has a significant effect on the dependent variable, namely Community Welfare. This can be seen in the Coefficient table through hypothesis testing, it can be seen that the calculation results partially have a significant and significant effect on the Community Welfare variable.

Keywords: Corporate social responsibility; Public welfare

\section{PENDAHULUAN}

Program CSR merupakan investasi bagi perusahaan demi pertumbuhan dan berkelanjutan perusahaan bukan lagi dilihat sebagai sarana biaya melainkan menjadi sarana laba (profit centre). Menurut Bambang dan Melia (2010) Corporate Social Responsibility merupakan peningkatan kualitas kehidupan mempunyai arti adanya kemampuan manusia sebagai individu anggota komunitas untuk dapat menikmati serta memanfaatkan lingkungan hidup termasuk perubahan-perubahan yang ada sekaligus memelihara. Atau dengan kata lain merupakan cara perusahaan mengatur proses usaha untuk memproduksi dampak positif pada komunitas. Implementasi Corporate Social Responsibility (CSR) Menurut Grindle dalam AlMuhajir Haris \& Eko Priyo Purnomo (2016) menjelaskan bahwa Implementasi kebijakan menghubungkan antara tujuan kebijakan dan realisasinya dengan hasil kegiatan pemerintah.

Selanjutnya menurut Imron (2012), kesejahteraan hidup masyarakat dipahami sebagai kesejahteraan sosial. Imron (2012) menambahkan pada Pasal 1 ayat 1 Undang-Undang No.11 tahun 2009 tentang Kesejahteraan Sosial: "Kesejahteraan Sosial adalah kondisi terpenuhinya kebutuhan material, spiritual, dan sosial warga negara agar dapat hidup layak dan mampu mengembangkan diri, sehingga dapat melaksanakan fungsi sosialnya".

PT. Indonesia Asahan Aluminium (Persero) yang bergerak di sektor peleburan Aluminium. PT Inalum adalah perusahaan Badan Usaha Milik Negara (BUMN) yang berfokus pada bidang peleburan Aluminium. PT Inalum (Persero) resmi menjadi BUMN pada tanggal 19 Desember 2013. Lokasi utama PT Inalum (Persero) 
berada di Kuala Tanjung Kecamatan Sei Suka, Kabupaten Batu Bara, Sumatera Utara. PT Inalum (Persero) merupakan induk holding dari PT Antam, PT Bukit Asam, PT Timah dan PT Freeport Indonesia sebagai anggota holding. Produk yang dihasilkan dari PT Inalum (Persero) adalah Aluminium Ingot, Aluminium Alloy, dan Aluminium Billet. Sebagai bentuk tanggung jawab terhadap lingkungan, PT. Inalum (Persero) memberikan kontribusi bagi masyarakat lokal melalui program CSR. Program CSR yang dilakukan diharapkan dapat mensejahterakan masyarakat sekitar.

Hal ini seiring dengan hasil penelitian yang dilakukan Farida (2014), terdapat pengaruh yang signifikan antara Corporate Social Responsibility terhadap kesejateraan masyarakat. Hasil ini juga sesuai dengan penelitian Aisyah (2018) yang menyatakan bahwa Program CSR berpengaruh secara postif dan signifikan terhadap peningkatan kesejahteraan masyarakat. Namun pernyataan diatas tidak sejalan dengan penelitian yang dilakukan oleh Nirmaya el.,all (2014) yang menemukan tidak ada perbedaan signifikan antara kesejahteraan subjektif dari keluarga penerima program CSR dan keluarga nonpenerima program CSR. Selanjutnya Astiti dan Saitri (2016) yang menemukan bahwa CSR berpengaruh negatif terhadap kesejahteraan masyarakat namun CSR berpengaruh positif terhadap citra perusahaan. Dari hasil penelitian yang dilakukan sebelumnya. Maka rumusan masalah dalam penelitian ini adalah Bagaimana pengaruh CSR dalam meningkatkan kesejahteraan masyarakat Kecamatan Sei Suka, Kabupaten Batu Bara. Untuk itu penelitian ini bertujuan mengetahui sejauh mana program CSR yang dilakukan PT. Inalum (persero) dalam kesejahteraan masyarakat dan keefektifan program CSR yang dijalankan PT. Inalum (Persero) di Kecamatan Sei Suka, Kabupaten Batu Bara. Urgensi penelitian ini dapat memberikan kontribusi kepada perusahaan-perusahaan mengenai pentingnya program CSR bagi masyarakat sehingga dapat mendongkrak dan menciptakan kesejahteraan masyarakat lokal.

\section{METODE}

Populasi dalam penelitian merupakan wilayah yang ingin diteliti oleh peneliti. Menurut Sugiyono (2016) "Populasi adalah wilayah generalisasi yang terdiri atas obyek/subyek yang mempunyai kualitas dan karakteristik tertentu yang ditetapkan oleh peneliti untuk dipelajari dan kemudian ditarik kesimpulanya. Dalam penelitian ini populasi adalah Masyarakat Kabupaten Batubara yaitu Kecamatan Sei Suka. Adapun alasannya adalah karena daerah tersebut merupakan lingkungan kawasan PT Inalum (Persero). Berdasarkan hasil penelitian yang peneliti lakukan, jumlah masyarakat Kecamatan Sei Suka yang akan menjadi populasi pada penelitian ini adalah sebanyak 56.078 jiwa (data BPS Kabupaten Batubara tahun 2019).
Sampel merupakan bagian dari populasi yang ingin di teliti oleh peneliti. Menurut Sugiyono (2016) Sampel adalah bagian dari jumlah dan karakteristik yang dimiliki oleh populasi tersebut. Teknik sampling yang digunakan dalam penelitian ini adalah metode non probability sampling yaitu metode pemilihan sampel, dimana setiap anggota populasi tidak mempunyai peluang yang sama untuk dipilih menjadi anggota sampel. Jenis teknik non probability sampling yang digunakan dalam penelitian ini adalah purposive sampling yaitu teknik penarikan sampel dengan pertimbangan tertentu. Banyaknya sampel dihitung dengan menggunakan rumus Slovin yaitu:

$$
\begin{aligned}
n & =\frac{\mathrm{N}}{1+\mathrm{N} \cdot \mathrm{e}^{2}} \\
n & =\frac{56078}{1+56078 \cdot(10 \%)^{2}} \\
n & =\frac{56078}{560,79} \\
n & =100 \text { responden. }
\end{aligned}
$$

\section{Keterangan:}

$\mathrm{n}=$ Jumlah sampel

$\mathrm{N}=$ Ukuran populasi

$\mathrm{e}=$ Taraf kesalahan yaitu $10 \%$

Pertama, Persiapan Penelitian (Potensi dan Masalah). Tahap ini meliputi latar belakang masalah dan fenomena yang terjadi. Kedua, Penyusunan Instrumen meliputi : Mengkaji teoriteori tentang suatu konsep yang hendak diukur dengan angket / kuisioner, observasi dan wawancara. Ketiga, Uji validitas Instrumen yakni merumuskan konstruk dari variabel tersebut selanjutnya membuat dimensi, indikator dan jumlah butir untuk setiap dimensi dan indikator, menuliskan butir-butir instrumen yang berbentuk pernyataan, Lalu validasi data berupa pemeriksaaan pakar atau melalui panel yang pada dasarnya menelaah seberapa jauh butir-butir instrument yang dibuat secara tepat dapat mengukur indikator. Keempat, Revisi Instrumen, meliputi : Perbaikan atau saran dari pakar atau berdasarkan hasil panel. Kelima, Validasi Data Setelah konsep instrument dianggap valid secara teoritik atau secara konseptual maka dilakukan Metode atau cara untuk mencapai tujuan yang telah ditetapkan. Keenam, Pengolahan Data meliputi : Setelah data didapatkan maka dilakukan pengolahan data yakni proses mengartian data-data yang didapat dari lapangan sesuai dengan tujuan, rancangan dan sifat penelitian. Ketujuh, Interpretasi hasil dengan tahap yang dilakukan untuk menggabungkan hasil yang telah diolah sebelumnya guna menciptakan sebuah makna dari adanya data yang telah dikumpulkan.

\section{HASIL DAN PEMBAHASAN Pengujian Regresi Linier Sederhana}


Suci Etri Jayanti S dan Rusmewahni, Analisis Pengaruh Program CSR PT. Indonesia Asahan Aluminium (PERSERO) dalam Meningkatkan Kesejahteraan Masyarakat Kabupaten Batu Bara, Sumatera Utara

Pengujian regresi linier sederhana untuk mengetahui arah hubungan antara variabel independen yaitu Corporate Social Responsibility (CSR) terhadap variabel dependen Kesejahteraan masyarakat. Analisis data dalam penelitian ini menggunakan analisis regresi linier sederhana dengan menggunakan SPSS 17.0 for windows. Analisis variabel dijelaskan dalam uraian berikut:

Tabel 1. Hasil Regresi Linier Sederhana Coefficients $^{\mathrm{a}}$

\begin{tabular}{|c|c|c|c|c|c|}
\hline \multirow[b]{2}{*}{ Model } & \multicolumn{2}{|c|}{$\begin{array}{l}\text { Unstandardized } \\
\text { Coefficients }\end{array}$} & \multirow{2}{*}{$\begin{array}{c}\begin{array}{c}\text { Standardized } \\
\text { Coefficients }\end{array} \\
\text { Beta }\end{array}$} & \multirow[b]{2}{*}{$\mathrm{T}$} & \multirow[b]{2}{*}{ Sig. } \\
\hline & B & $\begin{array}{l}\text { Std. } \\
\text { Error }\end{array}$ & & & \\
\hline 1 (Constant) & 8.287 & 1.066 & & 7.775 & .000 \\
\hline CSR & .640 & .085 & .604 & 7.508 & .000 \\
\hline
\end{tabular}

a. Dependent Variable: Kesejahteraan Masyarakat

Berdasarkan nilai signifikansi dari tabel coefficients diperoleh nilai signifikansi sebesar $0.000<$ 0.05 , sehingga dapat disimpulkan bahwa variabel Corporate Social Responsibility (CSR) (X) berpengaruh terhadap variabel Kesejahteraan masyarakat (Y). Berdasarkan nilai t, diketahui nilai $t_{\text {hitung }}$ sebesar 7.508 $>t_{\text {tabel }} 1.66$, sehingga dapat disimpulkan bahwa variabel Corporate Social Responsibility (CSR) (X) berpenaruh terhadap variabel Kesejahteraan masyarakat (Y).

\section{Koefisien Determinasi $\left(\mathbf{R}^{2}\right)$}

Koefisien determinasi digunakan untuk melihat seberapa besar kontribusi variabel bebas terhadap variabel terikat. Dengan kata lain nilai koefisen determinan digunakan untuk mengukur besarnya kontribusi variabel yang diteliti $\mathrm{X}$ dan $\mathrm{Y}$ sebagai variabel terikatnya.

Semakin besar nilai koefisien determinasi maka semakin baik kemampuan variabel $\mathrm{X}$ menerangkan variabel Y. Jika determinasi $\left(\mathrm{R}^{2}\right)$ semakin besar (mendekati 1), maka dapat dikatakan bahwa pengaruh variabel $\mathrm{X}$ adalah besar terhadap variabel $\mathrm{Y}$.

Hal ini menunjukkan model yang digunakan semakin kuat untuk menerangkan pengaruh variabel $X$ terhadap variabel $Y$. Sebaliknya jika determinasi $\left(R^{2}\right)$ semakin kecil (mendekati nol), maka dapat dikatakan bahwa pengaruh variabel $\mathrm{X}$ terhadap variabel $\mathrm{Y}$ semakin kecil. Hal ini menunjukkan bahwa model yang digunakan semakin tidak kuat untuk menerangkan pengaruh variabel $\mathrm{X}$ terhadap variabel $\mathrm{Y}$.

Nilai yang dipergunakan dalam melihat koefisien determinasi dalam penelitian ini adalah pada kolom adjusted $R$ square. Hal tersebut dikarenakan nilai adjusted $R$ square tidak rentan pada penambahan variabel bebas. Nilai koefisien determinasi dapat dilihat pada Tabel 2 berikut :

Tabel 2. Koefisien Determinasi

\begin{tabular}{|l|c|r|r|r|}
\hline \multicolumn{7}{|c}{ Model Summary } \\
\hline Model & \multicolumn{1}{|c|}{ R } & R Square & $\begin{array}{c}\text { Adjusted R } \\
\text { Square }\end{array}$ & $\begin{array}{c}\text { Std. Error of } \\
\text { the Estimate }\end{array}$ \\
\hline 1 & $.604^{\mathrm{a}}$ & .365 & .359 & .92904 \\
\hline
\end{tabular}

a. Predictors: (Constant), $\mathrm{X}$

Berdasarkan tabel 2 dapat diketahui besarnya nilai adjusted $\mathrm{R}$ square sebesar 0.359 atau $35.9 \%$ Hal ini menunjukkan bahwa Variabel Corporate Social Responsibility (CSR) (X) dapat menjelaskan Variabel Kesejahteraan masyarakat $(\mathrm{Y})$ sebesar $35.9 \%$, sisanya sebesar $64.1 \%(100 \%$ - 35.9\%) dijelaskan oleh variabel lain di luar model penelitian ini.

\section{Uji Hipotesis \\ Uji Parsial (Uji t)}

Uji statistik $\mathrm{t}$ disebut juga sebagai uji signifikasi individual. Uji ini menunjukkan seberapa jauh pengaruh variabel independen secara parsial terhadap variabel dependen.

Dalam penelitian ini, uji hipotesis parsial dilakukan pada setiap variabel independen seperti pada Tabel berikut ini:

Tabel 3. Hasil Uji t Coefficients $^{\mathrm{a}}$

\begin{tabular}{|c|c|c|c|c|c|}
\hline \multirow[b]{2}{*}{ Model } & \multicolumn{2}{|c|}{$\begin{array}{l}\text { Unstandardized } \\
\text { Coefficients }\end{array}$} & \multirow{2}{*}{$\begin{array}{c}\begin{array}{c}\text { Standardized } \\
\text { Coefficients }\end{array} \\
\text { Beta }\end{array}$} & \multirow[b]{2}{*}{$t$} & \multirow[b]{2}{*}{ Sig. } \\
\hline & B & $\begin{array}{l}\text { Std. } \\
\text { Error }\end{array}$ & & & \\
\hline (Constant) & 8.287 & 1.066 & & 7.775 & .000 \\
\hline CSR & .640 & .085 & .604 & 7.508 & .000 \\
\hline
\end{tabular}

a. Dependent Variable: Kesejahteraan Masyarakat

Berdasarkan tabel diatas, dapat disimpulkan Nilai $t_{\text {hitung }}$ untuk variabel Corporate Social Responsibility (CSR) sebesar 7.508 dengan signifikansi sebesar 0.000 sedangkan $t_{\text {tabel }}$ pada $\alpha=0.05$ adalah 1.66. Hal ini menunjukkan bahwa $t_{\text {hitung }}(7.705)>t_{\text {tabel }}(1.66)$ dan nilai probabilitas $0.000<0.05$ maka $H_{0}$ ditolak dan $H_{a}$ diterima. Dengan demikian dapat disimpulkan bahwa Corporate Social Responsibility (CSR) berpengaruh secara signifikan terhadap Kesejahteraan masyarakat. Nilai koefisien yang positif menunjukkan bahwa Corporate Social Responsibility (CSR) berpengaruh positif dan signifikan terhadap Kesejahteraan masyarakat. 


\section{SIMPULAN}

Berdasarkan penjelasan dan analisis data yang telah dilakukan oleh peneliti terkait Pengaruh Corporate Social Responsibility (CSR) terhadap Kesejahteraan Masyarakat pada PT. Indonesia Asahan Aluminim (Persero) maka dapat ditarik kesimpulan sebagai berikut:

Berdasarkan hasil Uji Validitas dan Reliabilitas yang dilakukan, dinyatakan bahwa 7 pernyataan yang mewakili vaiabel adalah Valid dan Reliabel. Dan untuk Uji Reliabilitas dapat dibuktikan dari nilai Cronbach Alpha > 0.6 sehingga dapat disimpulkan bahwa semua indikator yang digunakan dalam penelitian ini dinyatakan Reliabel. Berdasarkan hasil Uji Normalitas diketahui bahwa nilai signifikansi $0.091>0.05$, maka dapat disimpulkan bahwa seluruh variabel berdistribusi normal. Berdasarkan Uji Multikolinearitas bahwa nilai tolerance dari Variabel CSR (X) sebesar 1 lebih besar dari 0,10 sedangkan nilai VIF dari Variabel CSR (X) sebesar 1, lebih kecil dari 10. Berdasarkan hasil perhitungan bahwa nilai tolerance semua variabel bebas lebih besar dari 0,10 dan nilai VIF semua variabel bebas juga lebih kecil dari 10 sehingga tidak terjadi gejala korelasi pada variabel bebas. Maka tidak adanya gejala multikolinearitas antar variabel bebas dalam model regresi. Berdasarkan Uji Heteroskedastisitas pola data menyebar sempurna, sebagian berada di atas titik nol dan sebagian lagi menyebar di bawah titik nol. Maka dapat disimpulkan tidak terdapat gejala heteroskedastisitas dalam model regresi.

Dari hasil Analisis Regresi Linier Sederhana menunjukkan bahwa Corporate Social Responsibility (CSR) berpengaruh positif terhadap Kesejahteraan Masyarakat pada PT. Indonsia Asahan Aluminium (Persero). Berdasarkan Uji Koefisien Determinasi, nilai $\mathrm{R}$ menyatakan bahwa nilai adjusted $\mathrm{R}$ sebesar 35.9\% Kesejahteraan Masyarakat pada PT Indonesia Asahan Aluminium (Persero) dapat dipengharui oleh Corporate Social Responsibility (CSR), sedangkan sisanya $63.1 \%$ dipengaruhi oleh variabel lain yang tidak diteliti dalam penelitian ini. Dari hasil analisa secara parsial (Uji t), variabel independen Corporate Social Responsibility (CSR) berpengaruh secara signifikan terhadap variabel dependen yaitu Kesejahteraan Masyarakat. Hal ini dapat dilihat pada tabel Coefficient melalui pengujian hipotesis dapat diketahui hasil perhitungan secara parsial memiliki pengaruh dan nyata (signifikan) terhadap variabel Kesejahteraan Masyarakat.

\section{DAFTAR PUSTAKA}

Aisyah Amini. 2018. Pengaruh Program Corporate Social Responsibility (CSR) Terhadap Peningkatan Kesejahteraan Masyarakat dalam Perspektif Ekonomi Islam(Studi pada implementasi CSR PT. Pertamina Geothermal Energy (PGE) Desa Pagar Alam dan Desa Ngarip Kecamatan UluBelu Kabupaten Tanggamus. Universitas Islam Negeri Raden Intan Lampung.
Al-Muhajir Haris dan Eko Priyo Purnomo, "Implementasi CSR (Corporate Social Responsibility) PT. Agung Perdana Dalam Mengurangi Dampak Kerusakan Lingkungan”, Jurnal Ilmu Pemerintahan \& Kebijakan Publik Universitas Muhammadiyah Yogyakarta, Vol. 3 No. 2, Juni 2016, hlm. 213.

Astiti, Ni Putu Yeni \&Saitri, Putu Wenny. 2016. "Pengaruh Corporate Social Responsibility Terhadap Kesejahteraan Masyarakat Dan Citra Perusahaan"Jurnal Bisnis Dan Kewirausahaan Vol.12. No.2.Universitas Mahasaraswati Denpasar.

Bambang dan Melia. 2010. Etika Bisnis dan Tanggung Jawab Sosial Perusahaan Di Indonesia. Edisi Pertama. Rekayasa Sains, Bandung

Farida. 2014. Analisis Pengaruh Implementasi CSR Terhadap Kesejahtean Sosial Di Bmt Hapan Umat Kudus.Journal Of Islamics and Business.

Imron, A. 2012. "Strategi dan Usaha Peningkatan Kesejahteraan Hidup Nelayan Tanggulasari Mangunharjo Tugu Semarang dalam menghadapi perubahan iklim " Jurnal Riptek Vol. 6. No. 1Hal.2

Nirmaya, Gilar Cahya, Muflikhati, Istiqlaliyah \& Simanjuntak, Megawati. 2014. "Pengaruh Program Corporate Social Responsibility (CSR) Terhadap Kesejahteraan Keluarga Di Sekitar Tambang".Jur. Ilm. Kel. \& Kons. IPB.

Sugiyono. 2016. Metode Penelitian Kuantitatif dan Kualitatif dan R\&D. Edisi Baru Cetakan 2016. Alfabeta, Bandung 